\title{
Potensi Chlorella Sp. untuk Menyisihkan COD dan Nitrat dalam Limbah Cair Tahu
}

\author{
Titik Istirokhatun, Mustika Aulia, Sudarno \\ Departemen Teknik Lingkungan, Fakultas Teknik, Universitas Diponegoro, Jl. Prof H. Sudarto \\ $\mathrm{SH}$, Kampus Undip Tembalang, Semarang, Indonesia 50275 \\ e-mail: titik.istirokhatun@live.undip.ac.id
}

\begin{abstract}
Abstrak
Upaya untuk mengetahui potensi penggunaan limbah cair pemrosesan tahu sebagai media pertumbuhan mikroalga, penelitian ini dilakukan dengan membudidayakan mikroalga dalam berbagai konsentrasi. Jenis mikroalga yang dipilih adalah Chlorella sp. karena tingkat reproduksi yang tinggi. Kemampuan Chlorella sp. dalam menyisihkan kadar COD dan nitrat yang terkandung dalam limbah cair tahu juga diselidiki. Penelitian ini menguji tingkat pertumbuhan mikroalga, nilai kelimpahan sel mikroalga, penurunan kadar organik COD dan nitrat oleh Chlorella sp yang dikembangkan dalam media limbah cair tahu. Pertumbuhan optimum Chlorella sp didapatkan pada konsentrasi 30\% v/v limbah cair tahu yang dapat menurunkan COD dan nitrat masing-masing hingga $77,40 \%$ dan 30,03\%. Dari penelitian ini, dapat disimpulkan bahwa limbah cair tahu efektif digunakan sebagai media pertumbuhan mikroalga dan pada saat bersamaan, efektif untuk menghilangkan COD dan nitrat.
\end{abstract}

Kata kunci: Chlorella sp, tofu-processing wastewater, $C O D$, nitrat

\begin{abstract}
In order to examine the potential use of tofu-processing wastewater as growth media for microalgae, this research was conducted by cultivating microalgae in varying concentrations. The type of microalga selected in the experiment was Chlorella sp. due to its high reproductive rate. The ability of Chlorella sp. in removing the levels of COD and nitrate contained in the tofu liquid waste were also investigated. This study examined the microalgae growth rate, microalgae cell abundance values, reduced organic levels of COD and nitrate of Chlorella $s p$ which cultivated in tofu wastewater medium. The optimum growth of Chlorella $s p$ was found at $30 \% \mathrm{v} / \mathrm{v}$ of tofu wastewater which reduce COD and nitrate up to $77.40 \%$ and $30.03 \%$ respectively. From this study, we concluded that tofu-processing wastewater is effective to use as microalgae growth media and at the same time, effective to eliminate COD and nitrate.
\end{abstract}

Keywords: Chlorella sp., tofu-processing wastewater, COD, nitrate

\section{PENDAHULUAN}

Tahu merupakan salah satu produk olahan kedelai yang telah lama dikenal dan banyak digemari di Indonesia, bahkan menjadi favorit di beberapa negara Asia, karena kandungan protein nabatinya yang tinggi. Perkembangan industri tahu menjadi fenomena yang tak terelakkan. Keberadaannya selalu didukung baik oleh pemerintah maupun oleh masyarakat, sehingga industri ini berkembang dan tersebar luas baik di kota-kota besar maupun kecil di Indonesia. Di sisi lain, industri tahu merupakan sektor yang berpotensi dalam penyerapan tenaga kerja, terutama di daerah yang jumlah penduduknya padat.

Proses produksi tahu sangat intensif menggunakan air, sehingga limbah cair yang dihasilkan pun cukup besar. Untuk menghasilkan $80 \mathrm{~kg}$ tahu, diperlukan $60 \mathrm{~kg}$ kedelai dan 2.700-liter air, di mana sebagian besar dari air yang digunakan tersebut menghasilkan limbah cair sebanyak 2610 liter (REEP, 2012). Air limbah dari industri tahu sebagian besar dialirkan langsung tanpa pengolahan terlebih dahulu ke saluran pembuangan, sungai maupun badan air penerima lainnya. Hal ini menyebabkan limbah cair tahu seringkali menjadi masalah bagi lingkungan sekitarnya. Kebiasaan ini sebagai akibat minimnya pengetahuan para pengrajin tahu akan pentingnya kebersihan lingkungan. Anggapan bahwa mengolah limbah cair merupakan beban yang memberatkan, memperparah fenomena ini. Melimpahnya limbah cair tahu sebagai konsekuensi perkembangan industri yang meningkat, jika tidak ditangani secara tepat maka dikhawatirkan akan menyebabkan 
terganggunya kualitas lingkungan perairan di sekitar industri tahu (Rossiana, 2006).

Limbah cair industri tahu dapat menimbulkan pencemaran serius karena mengandung polutan organik yang cukup tinggi. Beberapa hasil penelitian menyebutkan bahwa konsentrasi COD (Chemical Oxygen Demand) di dalam air limbah industri tahu cukup tinggi yakni berkisar antara 7.000-10.000 mg/L, bersifat asam, yakni pada rentang $\mathrm{pH}$ 4-5. Ditinjau dari Peraturan Menteri Lingkungan Hidup No 5 Tahun 2014 tentang baku mutu air limbah, maka industri tahu memerlukan pengolahan limbah.

Parameter yang akan disisihkan dalam penelitian ini adalah COD dan nitrat. Nitrat adalah salah satu kontaminan yang sering dijumpai di dalam air. Keberadaannya dalam air minum dibatasi karena kadar berlebih dapat menyebabkan kelainan darah yang berpotensi fatal pada bayi di bawah usia 6 bulan yang disebut methemoglobinemia atau penyakit bayi biru (blue baby disease). Di sisi lain, kelebihan kadar nitrat dalam air dapat menciptakan kondisi yang menyulitkan serangga air atau ikan untuk bertahan hidup (Culligan-Nation, 2016; USGS, 2017).

Salah satu upaya yang bisa dilakukan untuk memanfaatkan limbah cair tahu adalah dengan menggunakan limbah tersebut sebagai media pertumbuhan mikroalga. Mikroalga yang dapat digunakan dalam pengolahan limbah salah satunya adalah Chlorella sp. Jenis mikroalga ini layak untuk dibudidayakan karena sifatnya yang mudah dan cepat berkembangbiak (Darsono, 2007). Pertumbuhan Chlorella sp. sangat ditentukan oleh ketersediaan nutrien dan kondisi lingkungan (Sylvester et al., 2002). Media pertumbuhan Chlorella sp. bukan merupakan lahan yang berair khusus, namun cukup dengan air yang mengandung nitrogen dan kaya akan zat organik. Berdasarkan karakteristik tersebut, limbah cair tahu merupakan salah satu bahan yang memungkinkan untuk digunakan sebagai media tumbuh Chlorella sp. (Sidabutar, 1999).

\section{Metodologi Penelitian}

Chlorella sp. diperoleh dari stok kultur bibit Balai Besar Pengembangan Budidaya Air Payau (BBPBAP) Jepara. Limbah cair tahu diperoleh dari hasil sampling di Industri Rumah Tangga daerah pemukiman Tandang. Digestion solution $\left(\mathrm{K}_{2} \mathrm{CrO}_{4}\right)$ didapatkan dari Merck \& Co., Inc (New York), larutan pereaksi $\mathrm{H}_{2} \mathrm{SO}_{4}$ diperoleh dari Mallinckrodt Pharmaceuticals
(England), dan $\mathrm{HCl}$ didapatkan Merck \& Co., Inc (New York). Kultivasi dilakukan menggunakan alat reaktor buble column yang dilengkapi dengan lampu 12Watt selama 24 jam terus-menerus. Kebutuhan $\mathrm{O}_{2}$ untuk mikroalga dipasok dari aerator yang sekaligus berfungsi untuk pengadukan. Setiap hari, optical density dari mikroalga diukur untuk mengetahui konsentrasi dan pertumbuhan sel mikroalga (Widayat dan hadiyanto, 2015). Perhitungan kepadatan sel Chlorella sp. dilakukan dengan menggunakan Haemocytometer Neubauer Improved (Isnansetyo dan Kurniastuty, 1995) produksi China.

\section{HASIL DAN PEMBAHASAN \\ Kepadatan Sel Mikroalga}

Pengukuran kepadatan sel dilakukan setiap hari selama 10 hari berturut-turut untuk dapat menentukan setiap fase pertumbuhan mikroalga. Hasil pengukuran kepadatan sel ditampilkan dalam Gambar 1.

Pertumbuhan sel Chlorella Sp dalam media limbah cair tahu diamati selama 10 hari dengan variasi konsentrasi limbah cair tahu $0-100 \%$ untuk mengetahui pengaruh konsentrasi limbah cair tahu terhadap pertumbuhan mikroalga. Pertumbuhan mikroalga terjadi dalam berbagai fase yaitu (i) fase lag,yaitu fase di mana bakteri menyesuaikan diri dengan lingkungannya, (2) fase log/eksponensial, merupakan fase pertumbuhan bakteri yang cepat, ditandai dengan aktifnya sel-sel yang dapat diamati, (3) fase stationer, yaitu fase di mana laju tumbuh dan kematian seimbang sehingga jumlah total bakteri yang hidup tetap, (4) fase penurunan pertumbuhan dan berakhir pada (5) fase kematian sel (Fogg, 1975). Fase lag pada penelitian ini terjadi sangat singkat, yaitu kurang dari 24 jam (pengamatan pada hari ke-1). Hal ini terlihat dari kepadatan sel Chlorella sp. yang sudah mengalami peningkatan. Pada fase lag ini Chlorella sp. sudah dapat beradaptasi dengan baik pada lingkungan yang baru kemudian terjadi pembelahan sel. Kemampuan mikroalga beradaptasi ini dipengaruhi oleh senyawa atau bahan organik dan anorganik dalam media yang akan menjadi sumber nutrisi dan dapat juga menjadi nutrisi pembatas bagi pertumbuhan. Jika salah satu nutrisi tidak tersedia dalam limbah atau jumlahnya terlalu besar maka proses reduksi senyawa organik dan pertumbuhan mikroalga akan terhambat. Menurut Prihantini (2005), salah satu faktor yang menentukan lamanya fase 
adaptasi adalah umur kultur yang digunakan sebagai inokulum. Fase adaptasi akan menjadi lebih singkat atau bahkan tidak terlihat apabila sel-sel yang diinokulasikan berasal dari kultur yang berada dalam fase eksponensial. Data kelimpahan sel Chlorella sp. pada konsentrasi limbah cair tahu 0-40\% ditampilkan dalam Tabel 1.

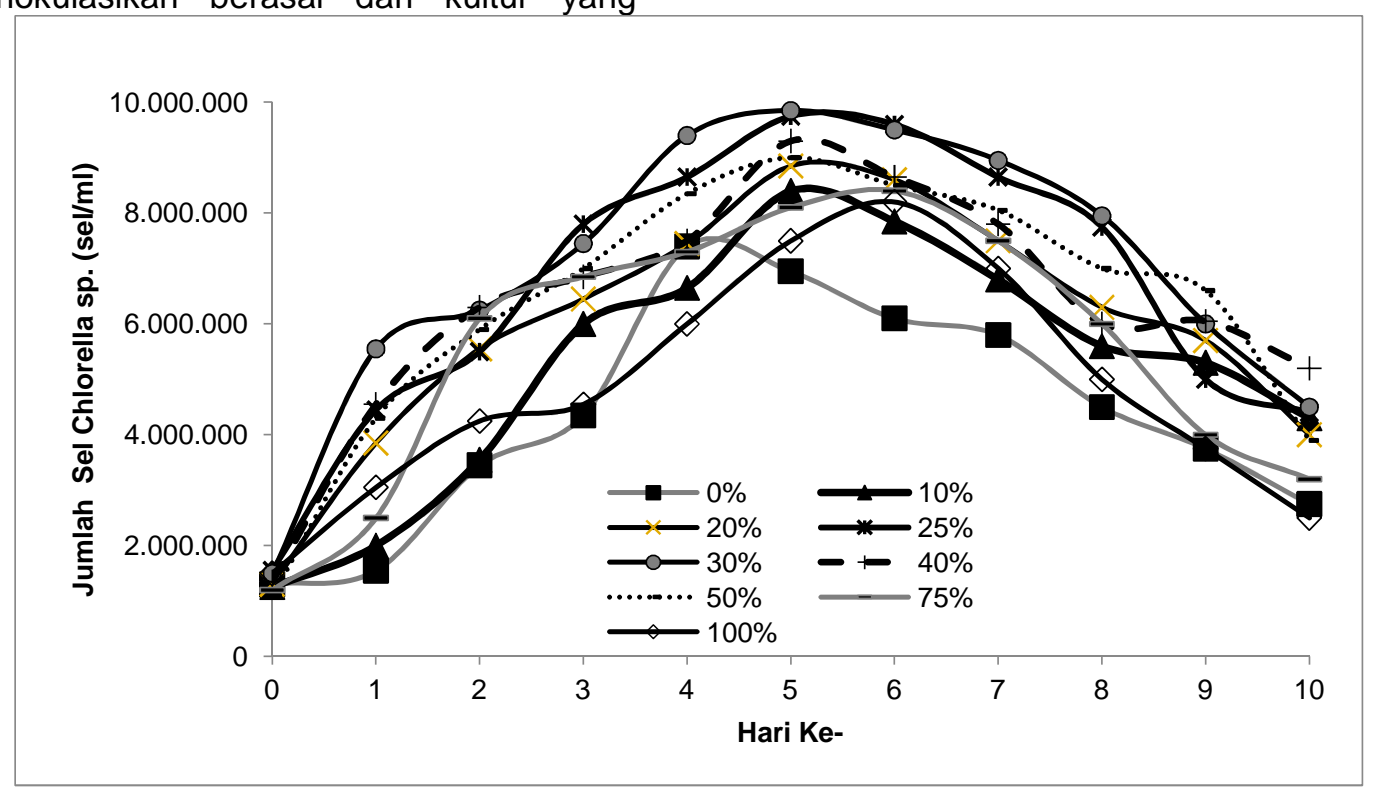

Gambar 1. Hubungan antara jumlah sel dengan waktu kultivasi

Tabel. 1. Kelimpahan Sel Chlorella sp.

\begin{tabular}{cccccc}
\hline Hari Ke- & \multicolumn{5}{c}{ Kelimpahan Sel $(\mathbf{x ~ 1 0} / \mathbf{m l})$} \\
\cline { 2 - 6 } & $\mathbf{0}$ & $\mathbf{1 0}$ & $\mathbf{2 0}$ & $\mathbf{3 0}$ & $\mathbf{4 0}$ \\
$\mathbf{0}$ & 130 & 125 & 130 & 150 & 135 \\
$\mathbf{1}$ & 155 & 200 & 385 & 555 & 455 \\
$\mathbf{2}$ & 345 & 355 & 555 & 625 & 630 \\
$\mathbf{3}$ & 435 & 600 & 645 & 745 & 685 \\
$\mathbf{4}$ & 740 & 665 & 745 & 940 & 750 \\
$\mathbf{5}$ & 695 & 840 & 885 & 985 & 930 \\
$\mathbf{6}$ & 610 & 785 & 860 & 950 & 865 \\
$\mathbf{7}$ & 580 & 680 & 750 & 895 & 780 \\
$\mathbf{8}$ & 450 & 560 & 630 & 795 & 600 \\
$\mathbf{9}$ & 375 & 530 & 570 & 600 & 605 \\
$\mathbf{1 0}$ & 275 & 430 & 400 & 450 & 520 \\
\hline
\end{tabular}

Fase eksponensial (log phase) diawali dengan pembelahan sel dan ditandai dengan naiknya laju pertumbuhan sehingga kepadatan populasi meningkat (Kawaroe, 2010). Pada penelitian ini, waktu dan kepadatan sel fase eksponensial dari berbagai konsentrasi berbeda-beda. Berdasarkan Gambar 1, fase eksponensial terendah terjadi pada konsentrasi $0 \%$ dengan jumlah rata-rata kepadatan sel $7.400 .000 \mathrm{sel} / \mathrm{ml}$ pada hari ke-4. Konsentrasi $0 \%$ (tanpa limbah) memiliki kadar nutrisi rendah karena sumber nutrisi didalam aquades tidak sebanyak sumber nutrisi yang terkandung didalam limbah cair tahu, sehingga menyebabkan pertumbuhan Chlorella sp. terhambat. Selain itu, faktor suhu, cahaya, aerasi dan $\mathrm{pH}$ yang diberikan selama proses kultur juga menjadi penunjang untuk membantu mikroalga melakukan pertumbuhan.

Fase eksponensial tertinggi terjadi pada konsentrasi $30 \%$ dengan kepadatan sel rata-rata $9.850 .000 \mathrm{sel} / \mathrm{ml}$ pada hari ke-5. Hal ini dikarenakan limbah cair tahu mengandung mineral-mineral anorganik dalam bentuk ion yang lebih mudah diserap dan dimanfaatkan oleh sel Chlorella sp. untuk pertumbuhannya. Selain itu juga, jumlah nutrien yang ada didalam limbah cair tahu sebanding dengan jumlah mikroalga yang memanfaatkan nutrien tersebut.

Fase stasioner dalam penelitian ini belum bisa teramati dengan seksama dikarenakan perhitungan pertumbuhan kepadatan sel mikroalga dilakukan selama 24 jam sekali. Jarak fase penurunan dan fase stasioner umumnya relatif singkat, sehingga dibutuhkan perhitungan dengan intensitas yang lebih dari sekali dalam 24 jam sesuai dengan kebutuhan peneliti.

Fase berikutnya adalah fase penurunan pertumbuhan yang ditandai dengan menurunnya jumlah kepadatan sel. Penurunan kepadatan sel Chlorella sp. pada masing-masing konsentrasi berbedabeda. Ketika konsentrasi $0 \%$, pertumbuhan bakteri mengalami penurunan jumlah sel pada hari ke-5. Pada konsentrasi $10 \%$, $20 \%, \quad 25 \%, \quad 30 \%, \quad 40 \%$ dan $50 \%$ pertumbuhan bakteri terjadi pada hari ke-7, sedangkan konsentrasi $75 \%$ dan $100 \%$ pada hari ke-8. Ketika konsentrasi limbah 
$0 \%$ maka jumlah nutrisi yang tersedia lebih sedikit dibandingkan dengan konsentrasi $100 \%$. Sehingga pada konsentrasi rendah mikroalga akan mengalami fase penurunan pertumbuhan sel yang lebih cepat dibandingkan pada saat konsentrasi limbah tinggi dengan kandungan nutrisi yang tinggi pula. Kepadatan sel mulai menurun dikarenakan nutrisi yang ada pada limbah tersebut sudah mulai berkurang seiring dengan waktu kultur dan laju kematian lebih tinggi dari laju pertumbuhan (fase kematian).

Fase selanjutnya adalah fase kematian sel. Fase kematian pada perlakuan $0 \%$ terjadi pada hari ke-6 dengan rata-rata 6.100.000 sel/ml menurun sampai hari ke10 sebesar $2.750 .000 \mathrm{sel} / \mathrm{ml}$. Kematian sel pada perlakuan $10 \%$ sampai $50 \%$ terjadi pada hari ke-9, sedangkan perlakuan $75 \%$ dan $100 \%$ terjadi pada hari ke-10. Dari hasil ini dapat diketahui bahwa semakin besar konsentrasi limbah cair tahu sebanding dengan waktu kematian sel yang semakin lama. Hal ini disebabkan karena kandungan nutrisi pada limbah cair tahu konsentrasi tinggi masih cukup tersedia untuk memenuhi kebutuhan sel dalam waktu yang lebih lama dibandingkan konsentrasi rendah dengan jumlah nutrisi yang rendah pula.

\section{Laju Pertumbuhan Mikroalga}

Menurut Krichnavaruk et al (2004), untuk menganalisa laju pertumbuhan mikroalga $(\mu)$ digunakan persamaan sebagai berikut:

dimana:

$$
\mu=\frac{\ln N_{\tau}-h_{1} N_{0}}{T_{L}-T_{0}}
$$

\section{sp. Disajikan dalam Gambar 2.}

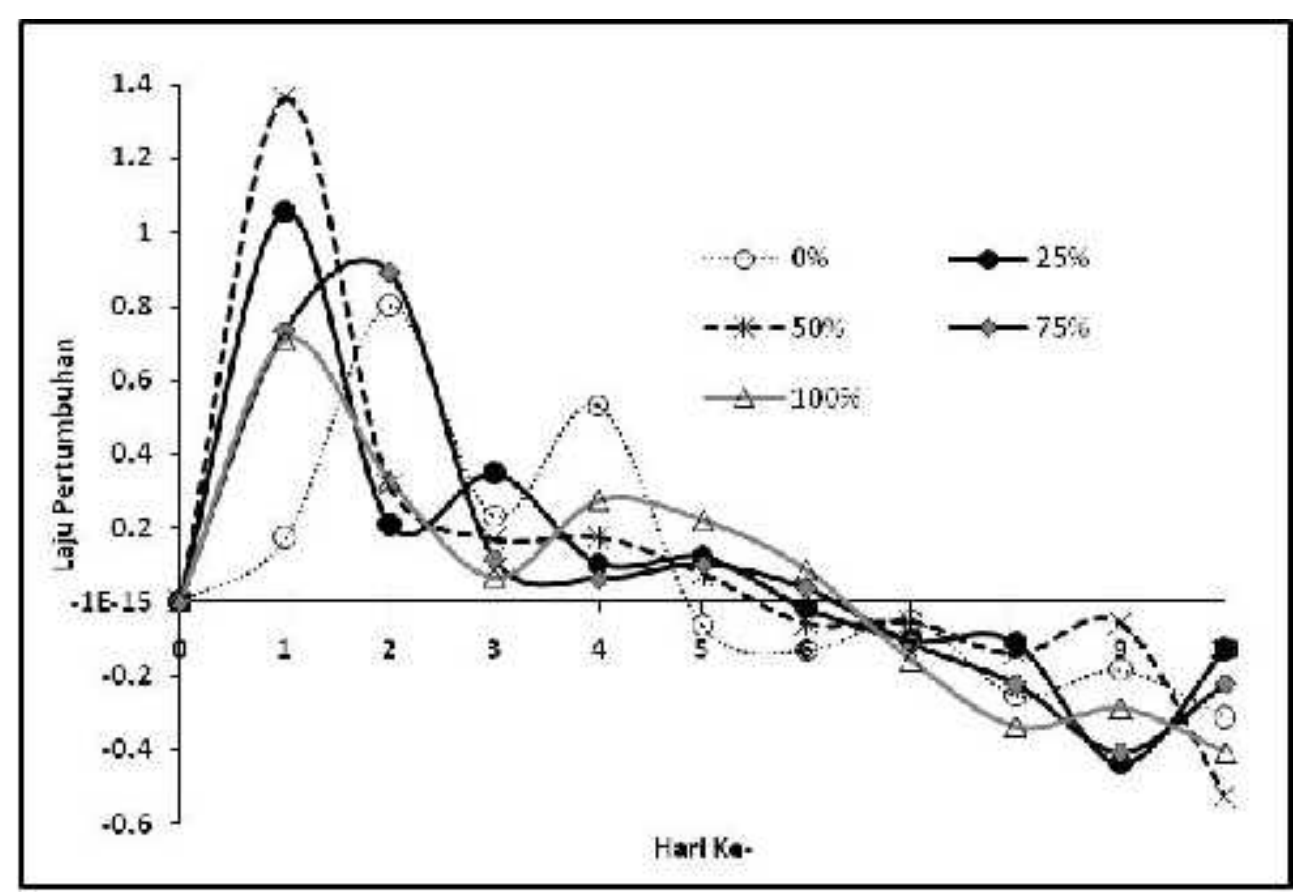

Gambar 2. Laju pertumbuhan Chlorella sp. pada berbagai variasi konsentrasi limbah cair tahu $(0,25,50,75$ dan $100 \%)$

Analisa laju pertumbuhan yang diperoleh dari penelitian didasarkan pada hasil perhitungan kepadatan sel mikroalga, untuk menentukan lama waktu yang diperlukan mikroalga dalam sekali pembelahan sel. Kepadatan sel dan laju pertumbuhan mikroalga dihitung setiap hari selama masa kultivasi sehingga dapat menggambarkan setiap fase pertumbuhan mikroalga.

Laju pertumbuhan menggambarkan kecepatan pertumbuhan sel-sel mikroalga persatuan waktu yang dapat dipakai sebagai tolak ukur untuk mengetahui daya dukung medium atau nutrien terhadap pertumbuhan dan pembelahan sel mikroalga (Wulandari, 2011). Pada 
konsentrasi $0 \%$, jumlah nutrien yang terkandung didalam aquades lebih sedikit jika dibandingkan dengan nutrien yang terkandung dalam limbah cair tahu konsentrasi $10-100 \%$, sehingga kebutuhan nutrien untuk mikroalga tidak dapat terpenuhi secara maksimal yang menyebabkan laju pertumbuhan menjadi terhambat. Saat masa pertumbuhan, laju pertumbuhan mikroalga akan meningkat hingga titik tertentu dan akan berkurang setelahnya. Hal ini dikarenakan pada hari pertama, limbah cair tahu masih menyimpan asupan nutrien yang banyak kemudian dari hari ke hari jumlah nutrien tersebut akan menurun karena kebutuhan konsumsi nutrien untuk mikroalga yang terus meningkat. Pada penelitian ini, laju pertumbuhan sel paling cepat terjadi pada saat konsentrasi limbah $30 \%$ yang dan pada konsentrasi $40 \%$, laju pertumbuhan sel mulai menurun. Hal ini menunjukkan bahwa konsentrasi $30 \%$ merupakan konsentrasi paling optimum dalam pertumbuhan sel.

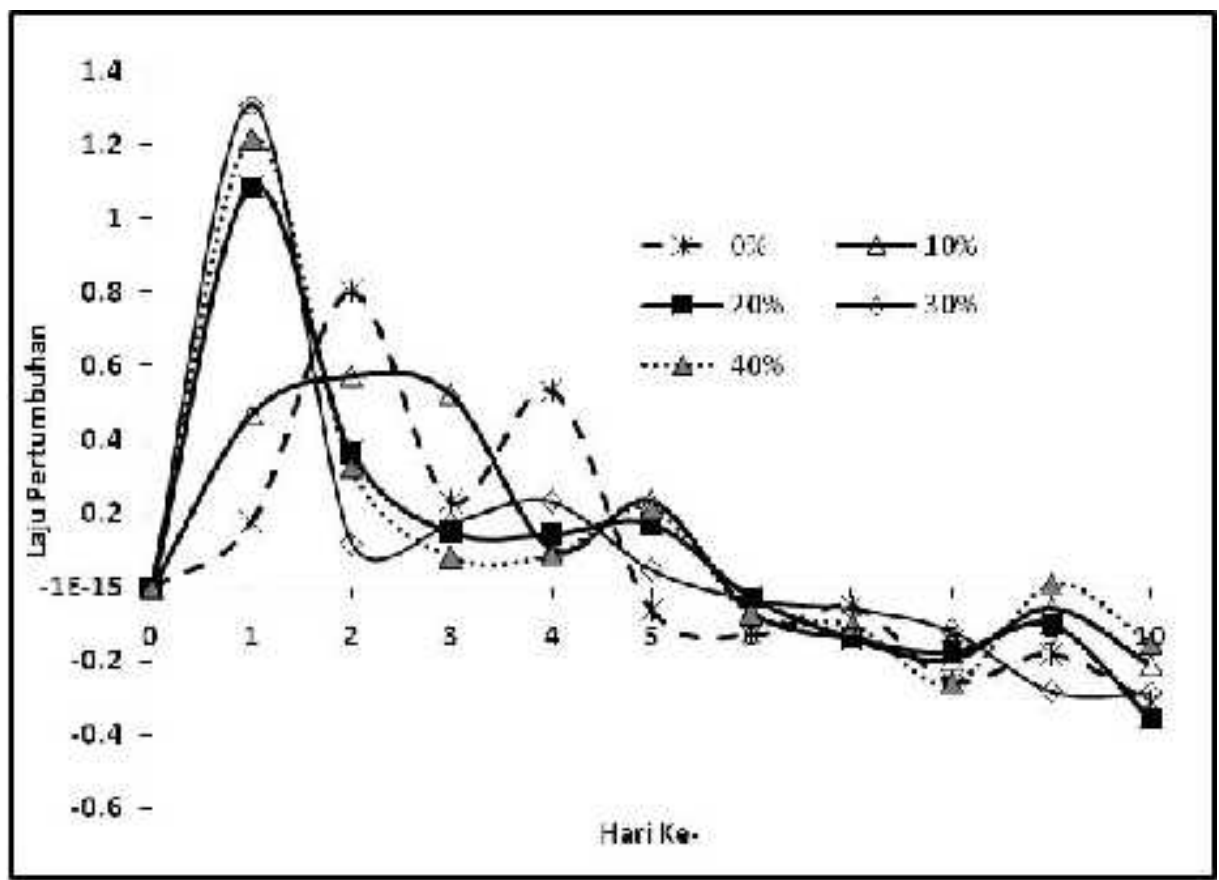

Gambar 3. Laju pertumbuhan Chlorella sp. pada berbagai variaasi konsentrasi limbah cair tahu $(0,10,20,30$, dan $40 \%)$

\section{Hubungan Kepadatan Sel dan Laju Pertumbuhan dengan Fase Hidup Mikroalga}

Mikroalga melewati fase-fase pertumbuhan yang penting semasa hidupnya. Pada fase lag, mikroalga melakukan adaptasi terhadap lingkungannya sesaat setelah ditanamkan ke dalam medium kultur baru. Meskipun mengalami metabolisme, pertumbuhan pada fase ini belum terlalu terlihat ditandai dengan kepadatan sel yang masih rendah, sebanding dengan laju pertumbuhan sel yang juga rendah (Prihantini, 2005). Atau dengan kata lain, laju pertumbuhan sel sebanding dengan kepadatan sel.

Seiring berjalannya waktu kultivasi, semakin banyak pula pembelahan sel yang terjadi dan mikroalga tumbuh mencapai fase berikutnya, yaitu fase eksponensial. Pada fase ini, pembelahan sel yang melimpah mengakibatkan kepadatan sel bertambah dan laju pertumbuhan juga akan meningkat secara signifikan (Kawaroe, 2010). Dari hal tersebut menunjukkan bahwa mikroalga memanfaatkan nutriennutrien yang ada dalam medium dengan sangat baik, sehingga kepadatan dan laju pertumbuhan pada fase ini dapat mencapai nilai yang maksimal dan digambarkan dalam grafik/kurva.

Nitrogen dan fosfor merupakan sumber nutrisi yang banyak dimanfaatkan oleh mikroalga di fase eksponensial, sehingga terjadi penurunan sumber nutrisi didalam medium yang menyebabkan mikroalga masuk ke fase berikutnya, yaitu fase penurunan laju pertumbuhan. Fase ini terjadi dikarenakan jumlah nutrisi yang tersedia tidak lagi dapat memenuhi kebutuhan konsumsi nutrisi mikroalga. Fase penurunan pertumbuhan ditandai dengan menurunnya nilai kepadatan dan laju pertumbuhan sel. Selanjutnya 
mikroalga memasuki fase stasioner, dimana pada fase ini jumlah mikroalga yang hidup dan mati kurang lebih hampir sama jumlahnya sehingga data kepadatan dan laju pertumbuhan sel yang diperoleh pun cenderung statis atau relatif tetap yang jika diplot ke grafik akan membentuk garis horizontal.

Namun, pada penelitian ini adalah tidak teramatinya fase stasioner dikarenakan perhitungan jumlah sel mikroalga hanya dilakukan sekali dalam sehari. Jarak fase penurunan pertumbuhan dan fase stasioner sangat singkat (bisa kurang dari 24 jam), sehingga disarankan untuk melakukan perhitungan sel mikroalga lebih dari sekali dalam rentang waktu 24 jam.

Fase terakhir yang dialami mikroalga adalah fase kematian. Dimana pada fase ini jumlah nutrisi di dalam medium sudah sangat terbatas jumlahnya yang mengakibatkan banyak mikroalga yang mati karena tidak memperoleh sumber nutrisi yang dibutuhkan. Dikarenakan tidak lagi terjadi pembelahan sel, maka laju kematian akan lebih tinggi dibandingkan laju pertumbuhan. Selain sumber nutrisi yang tidak mencukupi, pada fase ini kondisi lingkungan juga sudah tidak menunjang kehidupan mikroalga lagi.

\section{Penyisihan COD}

Pada penelitian ini, nilai COD tertinggi adalah pada perlakuan konsentrasi air limbah $100 \%$ sebesar 2876,67 $\mathrm{mg} / \mathrm{L}$ dan kandungan COD terendah pada konsentrasi $0 \%$, yaitu $121 \mathrm{mg} / \mathrm{L}$. Hasil penurunan konsentrasi COD pada limbah cair tahu sebelum dan setelah digunakan sebagai media pertumbuhan mikroalga ditampilkan pada Tabel 3.

Tabel 3. Efisiensi Removal COD (\%)

\begin{tabular}{|c|c|c|c|}
\hline \multirow{2}{*}{$\begin{array}{l}\text { Konsen } \\
\text { trasi \%) }\end{array}$} & \multicolumn{2}{|c|}{ COD } & \multirow{2}{*}{$\begin{array}{c}\text { Efisiensi } \\
\text { Removal (\%) }\end{array}$} \\
\hline & Awal & Akhir & \\
\hline 0 & 321,00 & 121,00 & 62,30 \\
\hline 10 & 377,67 & 121,00 & 67,96 \\
\hline 20 & 442,67 & 176,00 & 60,24 \\
\hline 25 & 511,00 & 207,67 & 59,36 \\
\hline 30 & 554,16 & 157,67 & 71,54 \\
\hline 40 & $1.658,33$ & $1.243,33$ & 25,02 \\
\hline 50 & $2.158,33$ & $1.443,33$ & 33,12 \\
\hline 75 & $3.325,00$ & $2.743,33$ & 17,49 \\
\hline 100 & $3.970,83$ & $2.876,67$ & 27,55 \\
\hline
\end{tabular}

Berdasarkan Tabel 3, terlihat hasil perhitungan yang menunjukkan bahwa penyisihan kandungan COD pada limbah cair tahu yang paling efektif dilakukan oleh mikroalga ialah pada konsentrasi $30 \%$ yaitu sebesar 71,549\%. Hal ini dikarenakan pada konsentrasi ini komposisi antara mikroalga dan nutrien ideal. Ketika konsentrasi air limbah ditingkatkan menjadi $40 \%$, efisiensi penyisihan COD mengalami penurunan. Hal ini menunjukkan bahwa konsentrasi $30 \%$ merupakan kondisi paling optimum penyisihan COD pada limbah cair tahu oleh Chlorella sp. Penurunan kadar COD pada konsentrasi $30 \%$ ditampilkan dalam Gambar 5. Untuk kadar COD, semakin tinggi kadar nitrogen didalam limbah cair tahu maka reduksi nilai COD semakin besar. Peningkatan kadar nitrogen ini akan membuat mikroalga tumbuh lebih baik dilihat dari semakin pesatnya pertumbuhan sel Chlorellavulgaris. Hal ini akan mendorong peningkatan kemampuan reduksi COD dari mikroalga. Selain itu, apabila kadar $\mathrm{CO}_{2}$ meningkat, maka reduksi nilai COD semakin kecil. Ini dikarenakan penambahan $\mathrm{CO}_{2}$ akan menghambat pertumbuhan dan kemampuan mereduksi COD pun menurun.

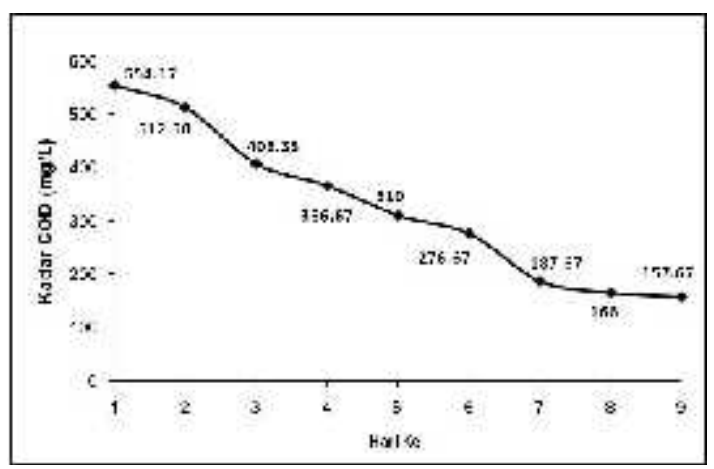

Gambar 5. Penyisihan COD

padakonsentrasi limbah 30\%

\section{Waktu Pemanenan yang Efektif dari Segi Biomassa dan Penyisihan COD}

Komponen utama biomassa adalah karbohidrat (berat kering $\pm 75 \%$ ) dan lignin $( \pm 25 \%)$ dimana pada beberapa tanaman komposisinya bisa berbeda-beda.

Untuk memperoleh biomassa yang melimpah, maka pemanenan dapat dilakukan ketika kelimpahan sel berada pada jumlah yang besar, yaitu pada fase eksponensial. Misalnya pada perlakuan dengan konsentrasi 50\%, kelimpahan sel paling tinggi teramati pada hari ke-5 sebesar $9.000 .000 \mathrm{sel} / \mathrm{mL}$ seperti terlihat pada gambar 6 .

Pemanenan dapat dilakukan pada hari ketujuh ini, namun perlu diperhatikan bahwa nilai COD pada hari ke-7 ini masih $1576 \mathrm{mg} / \mathrm{L}$. Artinya, COD masih belum memenuhi baku mutu sesuai dengan Peraturan Daerah Provinsi Jawa Tengah No. 5 Tahun 2012 tentang Baku Mutu Air Limbah Industri Tahu dan Tempe sebesar $275 \mathrm{mg} / \mathrm{L}$. Hal pertama yang harus dilakukan adalah dengan memanen mikroalga pada hari ke-7. Selanjutnya, untuk menurunkan nilai COD-nya yang 
masih tinggi yaitu dengan cara mengkultivasi kembali mikroalga yang dipanen kedalam medium limbah cair tahu. Karena pemanenan diambil pada saat pertengahan masa kultivasi, yaitu faseeksponensial dan COD sudah turun \pm $50 \%$ dari COD awal, sehingga kultivasi selanjutnya hanya memerlukan waktu setengah masa kultivasi saja, yaitu berkisar 5-7 hari. Dengan teknik seperti ini akan memberikan keuntungan, baik dari segi penyisihan COD maupun banyaknya biomassa yang bisa dipanen.

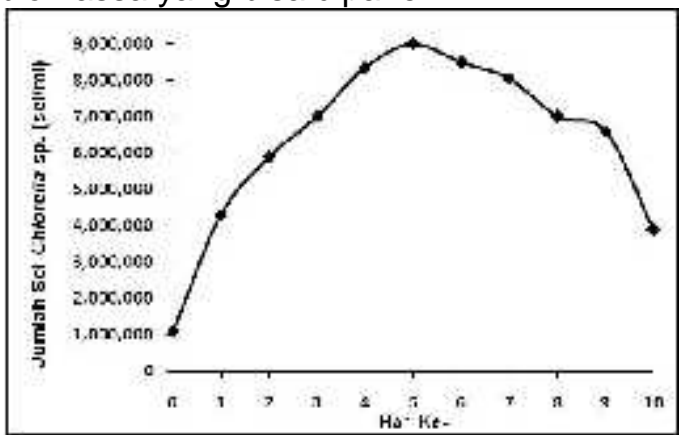

Gambar 6. Kurva Kelimpahan Sel pada Konsentrasi $50 \%$

\section{Hubungan antara Penurunan Kadar COD dengan Fase Pertumbuhan Chlorella sp}

Kadar bahan organik yang terkandung dalam limbah cair dapat diukur dari nilai COD. Nilai COD akan meningkat seiring dengan meningkatnya bahan organik di perairan. COD merupakan indikator pencemaran di badan air. Nilai COD menunjukkan keberadaan zat-zat organik yang secara ilmiah dapat dioksidasi melalui proses mikrobiologis sehingga mengakibatkan berkurangnya oksigen terlarut di perairan. COD juga menggambarkan banyaknya zat organik yang tidak mengalami penguraian dalam air. Nilai COD yang semakin rendah menunjukkan bahwa kandungan bahan organik dalam air tersebut semakin sedikit, dan hal ini juga menunjukkan bahwa tingkat pencemaran yang terjadi diperairan rendah.

Fase lag pada penelitian ini berlangsung kurang dari 24 jam ditunjukkan dari kepadatan sel yang terus mengalami kenaikan dan kadar COD terukur (pada kosentrasi $30 \%$ ) adalah 554,17 mg/L. Fase pertumbuhan selanjutnya yang dialami oleh sel mikroalga adalah fase eksponensial. Pada konsentrasi $30 \%$, fase eksponensial terjadi pada hari kelima penelitian karena jumlah sel tertinggi teramati pada hari tersebut. Kadar COD pada hari kelima sebesar $310 \mathrm{mg} / \mathrm{L}$.Jika dibandingkan dengan hari pertama, teramati bahwa kadar COD mengalami penurunan sebanyak 244,17 mg/L. Penurunan nilai COD terjadi karena adanya kegiatan mikroalga mengkonsumsi zat-zat organik didalam limbah cair tahu sehingga jumlahnya semakin berkurang. Fase penurunan laju pertumbuhan pada konsentrasi $30 \%$ terjadi pada hari ketujuh dengan kadar COD 187, $67 \mathrm{mg} / \mathrm{L}$. Dan fase yang terakhir adalah fase kematian. Fase kematian sel mikroalga teramati pada hari kesembilan ditandakan dengan lebih banyak sel mikroalga yang mati dibandingkan dengan sel yang masih hidup. Hal itu terlihat dari kurva laju pertumbuhan yang menunjukkan nilai negatif atau di bawah sumbu $X$.

Dari hasil penelitian menunjukkan bahwa fase pertumbuhan sel dilihat dari kepadatan sel berbanding terbalik dengan kandungan COD yang ada di dalam limbah cair tahu. Semakin besar atau semakin banyak jumlah mikroalga yang tumbuh dengan cara membelah diri, maka kandungan COD yang turun pun semakin banyak. Hal ini dikarenakan sel-sel mikroalga tumbuh dengan memanfaatkan zat-zat organik sebagai nutrien untuk pertumbuhannya.

\section{Penyisihan Nitrat}

Menurut Xin et al (2010), mikroalga dapat mengurangi senyawa polutan pada air limbah domestik atau rumah tangga. Nitrat yang terkandung dalam air limbah rumah tangga tersebut berfungsi sebagai sumber nitrogen mikroalga dalam pertumbuhannya. Mikroalga dapat mengurangi senyawa nitrogen sebesar 90\% pada limbah cair domestik atau rumah tangga. Dalam penelitian ini juga melakukan penyisihan nitrat pada limbah cair tahu. Hasil penyisihan nitrat ini ditampilkan pada Tabel 5.

Tabel 5. Efisiensi Removal Nitrat (\%)

\begin{tabular}{lllrc}
\hline Konsentrasi & Pengenceran & \multicolumn{2}{l}{$\begin{array}{l}\text { Absorbansi } \\
\text { 275 nm (A) }\end{array}$} & $\begin{array}{c}\text { Efisiensi } \\
\text { Removal (\%) }\end{array}$ \\
\cline { 2 - 4 } & & Awal (H1) & $\begin{array}{c}\text { Akhir } \\
\text { (H10) }\end{array}$ \\
& & & \\
$\mathbf{0}$ & 25 & 26,10 & 22,35 & 14,38 \\
$\mathbf{1 0}$ & 25 & 36,48 & 27,65 & 24,21 \\
$\mathbf{2 0}$ & 25 & 41,56 & 29,41 & 29,22 \\
\hline
\end{tabular}




\begin{tabular}{|c|c|c|c|c|}
\hline $\begin{array}{l}\text { Konsentrasi } \\
(\%)\end{array}$ & Pengenceran & $\begin{array}{l}\text { Absorbansi } \\
275 \mathrm{~nm}(\mathrm{~A})\end{array}$ & & $\begin{array}{c}\text { Efisiensi } \\
\text { Removal (\%) }\end{array}$ \\
\hline 25 & 25 & 50,39 & 38,47 & 23,66 \\
\hline 30 & 25 & 59,45 & 41,56 & 30,09 \\
\hline 40 & 25 & 63,20 & 53,04 & 16,07 \\
\hline 50 & 25 & 66,51 & 57,46 & 13,61 \\
\hline 75 & 25 & 81,75 & 75,57 & 7,56 \\
\hline 100 & 25 & 118,64 & 112,23 & 5,40 \\
\hline
\end{tabular}

Konsentrasi yang paling efektif untuk menyisihkan nitrat adalah konsentrasi 30\% sebesar $30,09 \%$. karena proses fotosintesis pada konsentrasi nitrat tersebut tidak terganggu sehingga proses penguraian $\mathrm{CO}_{2}$ menjadi ion $\left(\mathrm{HCO}_{3}^{-}\right)$. Sedangkan kemampuan penyisihan terendah pada konsentrasi $100 \%$ sebesar 5,40. Hal ini dikarenakan proses fotosintesis yang terhambat sebagai dampak dari terganggunya pembentukan klorofil karena kurangnya cahaya yang masuk kedalam sampel diakibatkan keruhnya sampel pada konsentrasi $100 \%$ dikarenakan tidak terdapatnya aquades sebagai pengencer limbah cair tahu. Semakin tinggi tingkat kenaikkan jumlah sel mikroalga juga mempengaruhi kemampuan air dalam melarutkan $\mathrm{CO}_{2}$, semakin jenuh medium, semakin sulit $\mathrm{CO}_{2}$ terlarut dalam air.

\section{KESIMPULAN}

Pertumbuhan sel tertinggi adalah pada perlakuan konsentrasi $30 \%$ sebesar 9.850.000 sel/mL sedangkan pertumbuhan sel terendah pada perlakuan dengan konsentrasi $0 \%$, yaitu $7.400 .000 \mathrm{sel} / \mathrm{mL}$.

Efisiensi removal COD yang paling efektif berada pada konsentrasi 30\% sebesar $71,549 \%$ dan yang terendah adalah konsentrasi $75 \%$, yaitu $17,494 \%$.

Penyisihan kadar nitrat tertinggi terlihat pada konsentrasi 30\% sebesar 30,03\% dan penyisihan terendah adalah konsentrasi $100 \%$ dengan nilai $7,56 \%$.

\section{DAFTAR PUSTAKA}

Culligan Nation. (2017). What are the effects of Nitrates in Drinking Water? https://www.culligannation.com/effectsof-nitrates-in-drinking-water/diakses 02 September 2017

Darsono. (2007). Pengolahan Limbah Cair Tahu Secara Anaerob dan Aerob. Universitas Atmajaya: Yogyakarta.

Fogg, GE. (1975). Algae Culture and Fitoplankton Ecology. University of Wiconsin Press: London.

Isnansetyo, A dan Kurniastuty. (1995). Teknik Kultur Phytoplankton dan Zooplankton. Kanisius: Yogyakarta.
Kawaroe, M. (2010). Mikroalga, Potensi dan Pemanfaatannya untuk Produksi Bio Bahan Bakar. Bogor: IPB Press

Krichnavaruk, S., Worapanne, Sorawit, dan Prasert. (2004). Optimal Growth Conditions and the Cultivation of Chaetoceros calcitrans in Airlift Photobioreactor. Chemical Engineering. 105: 91-98.

Peraturan Daerah Provinsi Jawa Tengah No. 5 Tahun 2012, Baku Mutu Air Limbah Rumah Sakit Di Propinsi Jawa Tengah.

Peraturan Menteri Lingkungan Hidup Republik Indonesia No. 5 Tahun 2014, Baku Mutu Air Limbah.

Prihantini, N, B., Putri, B., dan Yuniati, R. (2005). Pertumbuhan Chlorella sp. dalam Medium Ekstrak Tauge (Met) dengan Variasi pH Awal. MAKARA, SAINS. Vol 9, No.1:1-6. Depok: Departemen Biologi Fakultas MIPA, Universitas Indonesia.

REEP. (2012). Tofu production: a massive opportunity for RE biogas in Indonesia. In: The renewable energy and energy efficiency partnership (REEEP), Jakarta, Indonesia.

Rossiana, N. (2006). Uji Toksisitas Limbah Cair Tahu Sumedang Terhadap Reproduksi Daphnia carinata King. Karya IImiah: Universitas Padjajaran, Bandung.

Sidabutar EA. (1999). Pengaruh Jenis Medium Pertumbuhan Mikroalga Chlorella sp. Terhadap Aktivitas Senyawa Pemacu Pertumbuhan yang Dihasilkan. Skripsi. Teknologi Hasil Perikanan, Fakultas Perikanan dan Ilmu Kelautan, Institut Pertanian Bogor: Bogor.

Sylvester B., Nelvy D., Sudjiharno. (2002). Persyaratan BudidayaFitoplankton, Budidaya Fitoplankton \& Zooplankton. 10: 24-36.

USGS. (2017) Nitrogen and Water, https://water.usgs.gov/edu/nitrogen.ht $\mathrm{ml}$ diakses 02 September 2017

Widayat dan Hadiyanto. (2015). Pemanfaatan Limbah Cair Industri Tahu untuk Produksi Biomassa Mikroalga Nannochloropsis Sp 
sebagai Bahan Baku Biodiesel.

Reaktor Vol. 15 No. 4.

Wulandari, Suwartimah \& Hartati. (2011).

Komposisi jenis Dan Kelimpahan

Diatom Bentik di Muara Sungai Comal

Baru Pemalang. Semarang. Program

Studi IImu Kelautan, Fakultas

Perikanan dan IImu Kelautan, UNDIP. 16(1) 16-23

Xin, L., Hong-ying, H., Ke, G., Jia, Y. (2010). Growth and Nutrient Removal Properties of a Freshwater Microalga Scendesmus sp. LX1 Under Different Kinds of Nitrogen Sources. Ecological Engineering Vol. 36. 